\section{Kidney \\ Blood Pressure Research}

Original Paper

\title{
Downregulation of Peptide Transporters PEPT1 and PEPT2 by Oxidative Stress Responsive Kinase OSR1
}

\author{
Jamshed Warsi Bernat Elvira Rosi Bissinger Ekaterina Shumilina \\ Zohreh Hosseinzadeh Florian Lang \\ Department of Physiology I, University of Tübingen, Tübingen, Germany
}

\section{Key Words}

Peptide transport • Cell volume $\cdot$ OSR 1 - Voltage clamp $\bullet$ Xenopus oocytes

\begin{abstract}
Background/Aims: OSR1 (oxidative-stress-responsive kinase 1) participates in the regulation of renal tubular ion transport, cell volume and blood pressure. Whether OSR1 contributes to the regulation of organic solute transport remained; however, elusive. The present study thus explored the OSR1 sensitivity of the peptide transporters PEPT1 and PEPT2. Methods: CRNA encoding PEPT1 or PEPT2 were injected into Xenopus oocytes without or with additional injection of cRNA encoding wild-type OSR1, WNK1 insensitive inactive ${ }^{T 185 A} \mathrm{OSR} 1$, constitutively active ${ }^{T 185 E} O S R 1$, and catalytically inactive ${ }^{D 164 A}$ OSR1. Electrogenic peptide (glycine-glycine) transport was determined by dual electrode voltage clamp, the abundance of hemagglutinintagged PEPT2 (PEPT2-HA) by chemiluminescence. Results: In Xenopus oocytes injected with cRNA encoding PEPT1 or PEPT2, but not in oocytes injected with water, the dipeptide gly-gly (2 mM) generated an appreciable inward current $\left(\mathrm{I}_{\text {gly-gly }}\right.$ ). Coexpression of OSR1 significantly decreased $\mathrm{I}_{\text {gly-gly }}$ in both PEPT1 and PEPT2 expressing oocytes. The effect of OSR1 coexpression on $\mathrm{I}_{\text {gly-gly }}$ in PEPT1 expressing oocytes was mimicked by coexpression of T185EOSR1, but not of ${ }^{D 164 A} O S R 1$ or ${ }^{\mathrm{T} 185 \mathrm{~A}}$ OSR1. Kinetic analysis revealed that coexpression of OSR1 decreased maximal $\mathrm{I}_{\mathrm{gly}-\mathrm{gly}}$ OSR1 further decreased the PEPT2-HA protein abundance in the cell membrane. Conclusion: OSR1 has the capacity to downregulate the peptide transporters PEPT1 and PEPT2 by decreasing the carrier protein abundance in the cell membrane.
\end{abstract}

Copyright $@ 2014$ S. Karger AG, Basel

\section{Introduction}

The oxidative-stress-responsive kinase 1 (OSR1) is engaged in the regulation of epithelial transport [1-4]. OSR1 and the related SPAK (STE20-related proline/alanine-rich 


\section{Kidney \\ Blood Pressure Research}

Kidney Blood Press Res 2014;39:591-599
\begin{tabular}{l|l}
\hline DOI: $10.1159 / 000368469$ & (C) 2014 S. Karger AG, Basel
\end{tabular}

Published onine: December 15, 2014

www.karger.com/kbr

Warsi/Elvira/Bissinger/Shumilina/Hosseinzadeh/Lang: OSR1 Sensitive PEPT1/2 Activity

kinase) upregulate the $\mathrm{NaCl}$ ( $\mathrm{NCC}$ ) and $\mathrm{Na}^{+}, \mathrm{K}^{+}, 2 \mathrm{Cl}^{-}$(NKCC2) cotransporters and thus impact on blood pressure [2-17]. By stimulating cellular ion uptake SPAK and OSR1 contribute to cell volume regulation $[9,18]$. OSR1 is under the control of with-no-K(Lys) (WNK) kinases [5-7], which are similarly involved in the regulation of renal tubular ion transport and blood pressure [7, 19-22]. Mutations of genes encoding WNK kinases may lead to Gordon's syndrome, a monogenic disease characterized by hypertension and hyperkalaemia [23-26].

OSR1 and/or SPAK participate in the regulation of further epithelial transport processes, such as $\mathrm{Na}^{+}$coupled phosphate transport [27, 28], and $\mathrm{Na}^{+} / \mathrm{H}^{+}$exchanger [29].

The present study explored whether OSR1 modifies the peptide transporters 1 (PEPT1) and/or 2 (PEPT2), carriers accomplishing electrogenic cellular uptake of di- and tripeptides [30-32] including peptide-like drugs [30,31]. Regulators of peptide transporters include glucocorticoids [33], leptin [34] and growth hormone [35]. Signaling participating in the regulation of peptide transporters include phosphoinositide (PI) 3 kinase [36], phosphoinositide dependent kinase PDK1 [36], serum \& glucocorticoid inducible kinase SGK1 [37] and AMP activated kinase [38].

In order to possibly disclose an effect of OSR1 on the peptide transporters, cRNA encoding PEPT1 and PEPT2 were injected into Xenopus oocytes with or without cRNA encoding OSR1. In those oocytes peptide transport was estimated from peptide induced current.

\section{Materials and Methods}

\section{Constructs}

Constructs encoding PEPT1 or PEPT2 or PEPH2HA [39], wild-type OSR1, WNK1 insensitive inactive ${ }^{\mathrm{T} 185 \mathrm{~A}} \mathrm{OSR} 1$, constitutively active ${ }^{\mathrm{T} 185 \mathrm{E}} \mathrm{OSR} 1$, and catalytically inactive ${ }^{\mathrm{D} 164 \mathrm{~A}} \mathrm{OSR} 1$ [5], were used for generation of cRNA as described previously [27, 28, 40,41].

Voltage clamp in Xenopus oocytes

Xenopus oocytes were prepared as previously described $[42,43]$. Where not indicated otherwise, $10 \mathrm{ng}$ cRNA encoding PEPT1 or 20 ng cRNA encoding PEPT2 was injected on the first day and 10 ng cRNA encoding wild type OSR1, constitutively active ${ }^{\mathrm{T} 185 \mathrm{E}}$ OSR1, catalytically inactive ${ }^{\mathrm{D} 164 \mathrm{~A}} \mathrm{OSR} 1$ or WNK1 insensitive inactive ${ }^{\mathrm{T} 185 \mathrm{~A} O S R 1}$ were injected on the same day after preparation of the oocytes [44]. The oocytes were maintained at $17^{\circ} \mathrm{C}$ in $\mathrm{ND} 96$ solution containing (in $\mathrm{mM}$ ): $88.5 \mathrm{NaCl}, 2 \mathrm{KCl}, 1 \mathrm{MgC1} 1_{2}, 1.8 \mathrm{CaC1}{ }_{2}, 2.5 \mathrm{NaOH}, 5 \mathrm{HEPES}$ (pH 7.4), 5 sodium pyruvate $\left(\mathrm{C}_{3} \mathrm{H}_{3} \mathrm{NaO}_{3}\right)$, Gentamycin ( $\left.100 \mathrm{mg} / \mathrm{l}\right)$, Tetracycline (50 mg/l), Ciprofloxacin (1.6 mg/l), Theophylline $(90 \mathrm{mg} / \mathrm{l})$. The voltage clamp experiments were performed at room temperature 3 days after injection of cRNA encoding PEPT1 or 4 days after injection of cRNA encoding PEPT2. Concentration of cRNA and time for expression have been chosen according to previous experiences and preliminary experiments utilizing 10 or 20 ng cRNA and 3 or 4 days of expression. Comparisons were always made between oocytes injected with the same amount of cRNA and after identical expression times. Two-electrode voltage-clamp recordings were performed at a holding potential of $-70 \mathrm{mV}$. The data were filtered at $10 \mathrm{~Hz}$ and recorded with a Digidata A/D-D/A converter (1322 Axon Instruments) and Clampex 9.2 software for data acquisition and analysis (Axon Instruments) [45]. The control superfusate (ND96) contained (in mM): $93.5 \mathrm{NaCl}, 2$ $\mathrm{KCl}, 1.8 \mathrm{CaCl}_{2}, 1 \mathrm{MgCl}_{2}, 2.5 \mathrm{NaOH}$ and 5 HEPES, pH 7.4. [46]. Glycine-glycine was added to the solutions at a concentration of $2 \mathrm{mM}$, unless otherwise stated [41]. The flow rate of the superfusion was approx. $20 \mathrm{ml} /$ min, and a complete exchange of the bath solution was reached within about $10 \mathrm{~s}[40,47]$.

\section{Chemiluminescence}

For detection of PEPT2-HA cell surface expression, the oocytes were first incubated with primary mouse monoclonal anti-HA antibody conjugated to horseradish peroxidase (1:1000, Miltenyi Biotec Inc, CA, USA). Individual oocytes were placed in 96 well plates with $20 \mu$ l of SuperSignal ELISA Femto Maximum Sensitivity Substrate (Pierce) and chemiluminescence of single oocytes was quantified in a luminometer (Walter Wallac 2 plate reader, Perkin Elmer) by integrating the signal over a period of 1 sec [44]. Results display normalized relative light units. Integrity of the measured oocytes was assessed by visual control after the measurement to avoid unspecific light signals from the cytosol [46]. 


\section{Kidney \\ Blood Pressure Research}

Fig. 1. Coexpression of OSR1 decreases electrogenic peptide transport in PEPT1-expressing Xenopus oocytes. A: Representative original tracings showing glycine-glycine (2 mM) - induced current $\left(\mathrm{I}_{\text {gly-gly }}\right)$ in Xenopus oocytes injected with water (a) or expressing PEPT1 without (b) or with additional coexpression of wild type OSR1 (c). B: Arithmetic means \pm SEM $(n=20)$ of glycine-glycine (2 mM) - induced current $\left(\mathrm{I}_{\text {gly-gly }}\right)$ in Xenopus oocytes injected with water (dotted bar), or expressing PEPT1 without (white bar) or with (black bar) wild type PEPT1. ${ }^{* *}(\mathrm{p}<0.01)$ indicates statistically significant difference from the absence of OSR1.
Kidney Blood Press Res 2014;39:591-599

\begin{tabular}{l|l}
\hline DOI: $10.1159 / 000368469$ & C 2014 S. Karger AG, Basel
\end{tabular}

Publisned ontIne: vecember 15, 2014

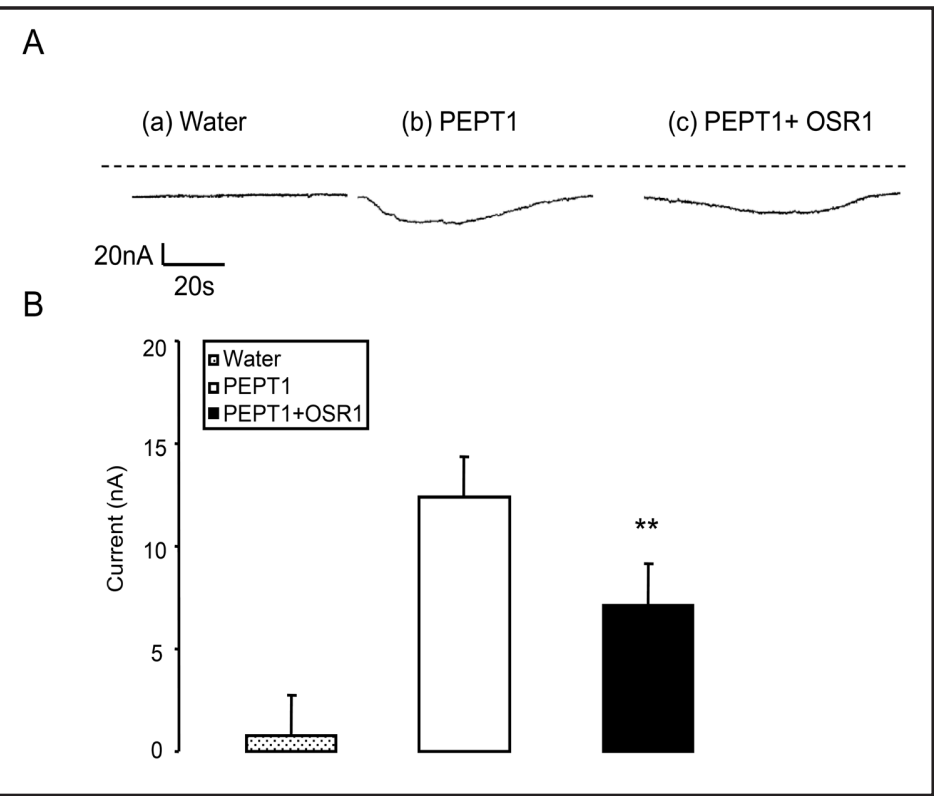

\section{Statistical analysis}

Data are provided as means \pm SEM, $n$ represents the number of oocytes investigated. All voltage clamp experiments were repeated with at least 2-3 batches of oocytes; in all repetitions qualitatively similar data were obtained. Data were tested for significance using ANOVA (Tukey test or Kruskal-Wallis test) or t-test, as appropriate. Results with $\mathrm{p}<0.05$ were considered statistically significant.

\section{Results}

The present study explored whether OSR1 contributes to the regulation of the peptide transporters PEPT1 and PEPT2. To this end, cRNA encoding PEPT1 or PEPT2 was injected into Xenopus oocytes with or without additional injection of cRNA encoding OSR1. Peptide transport was estimated from the inward current observed following addition of the dipeptide glycine-glycine $(2 \mathrm{mM})$ to the bath solution $\left(\mathrm{I}_{\text {gly-gly }}\right)$.

No $I_{\text {gly-gly }}$ was detectable in water-injected Xenopus oocytes (Fig. 1Aa) indicating that Xenopus oocytes did not express sizable endogenous electrogenic glycine-glycine transport. In Xenopus oocytes injected with cRNA encoding PEPT1, however, addition of glycineglycine to the bath was followed by the appearance of $\mathrm{I}_{\text {gly-gly }}$. The additional injection of cRNA encoding wild type OSR1 resulted in a significant decrease of $I_{\text {gly-gly }}$ in PEPT1 expressing Xenopus oocytes (Fig. 1).

Further experiments explored whether OSR1 was effective by modifying maximal transport rate and/or affinity of PEPT1. To this end, the oocytes were exposed to glycineglycine concentrations ranging from 0.01 to $5 \mathrm{mM}$. As illustrated in Fig. 2 the increase of peptide concentration was followed by an increase of $\mathrm{I}_{\text {gly-gly }}$ in both, Xenopus oocytes expressing PEPT1 alone and Xenopus oocytes expressing PEPT1 and OSR1. The increase of $\mathrm{I}_{\text {gly-gly }}$ was, however, larger in Xenopus oocytes expressing PEPT1 alone than in Xenopus oocytes expressing PEPT1 with OSR1. Calculation of maximal currents yielded values, which were significantly $(\mathrm{p}<0.05)$ higher in Xenopus oocytes expressing PEPT1 alone $(78 \pm 11$ $\mathrm{nA}, \mathrm{n}=10-12$ ) than in Xenopus oocytes expressing both, PEPT1 and OSR1 (48 $\pm 5 \mathrm{nA}, \mathrm{n}=$ 10-12). The glycine-glycine concentrations required for halfmaximal current $\left(\mathrm{K}_{\mathrm{M}}\right)$ were not 


\section{Kidney \\ Blood Pressure Research}

Fig. 2. Coexpression of OSR1 decreases maximal electrogenic peptide transport in PEPT1-expressing Xenopus oocytes. Arithmetic means \pm SEM $(\mathrm{n}=10$ 12) of glycine-glycine-induced current $\left(\mathrm{I}_{\text {gly-gly }}\right)$ as a function of glycine-glycine concentration in Xenopus oocytes expressing PEPT1 without (black squares), or with (black circles) additional coexpression of wild type OSR1.

Fig. 3. The effect of OSR 1 is mimicked by active ${ }^{\mathrm{T} 185 \mathrm{E}}$ OSR1 but not by inactive mutants ${ }^{\mathrm{D} 164 \mathrm{~A}}$ OSR 1 or ${ }^{\mathrm{T} 185 \mathrm{~A}}$ OSR1. A: Representative original tracings showing glycine-glycine (2 mM) - induced current $\left(\mathrm{I}_{\text {gly-gly }}\right)$ in Xenopus laevis oocytes injected with water (a), expressing PEPT1 alone (b) or with constitutively active T185EOSR1 (c), with catalytically inac-

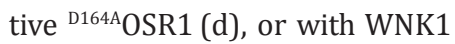
insensitive inactive ${ }^{\mathrm{T} 185 \mathrm{~A}}$ OSR1 (e). $\mathrm{B}$ : Arithmetic means \pm SEM $(\mathrm{n}=$ $8-10)$ of glycine-glycine (2 $\mathrm{mM})$ - induced current $\left(\mathrm{I}_{\text {gly-gly }}\right)$ in Xenopus laevis oocytes injected with water (dotted bar) or expressing PEPT1 without (white bar) or with constitutively active T185EOSR1 (black bar), with catalytically inactive ${ }^{\mathrm{D} 164 \mathrm{~A} O S R} 1$ (light grey bar) or with WNK insensitive inactive ${ }^{\mathrm{T} 185 \mathrm{~A}}$ OSR1 (dark grey bar). $* * *(\mathrm{p}<0.001)$ indicates statistically significant difference from the absence of ${ }^{\mathrm{T} 185 \mathrm{E}}$ OSR1.
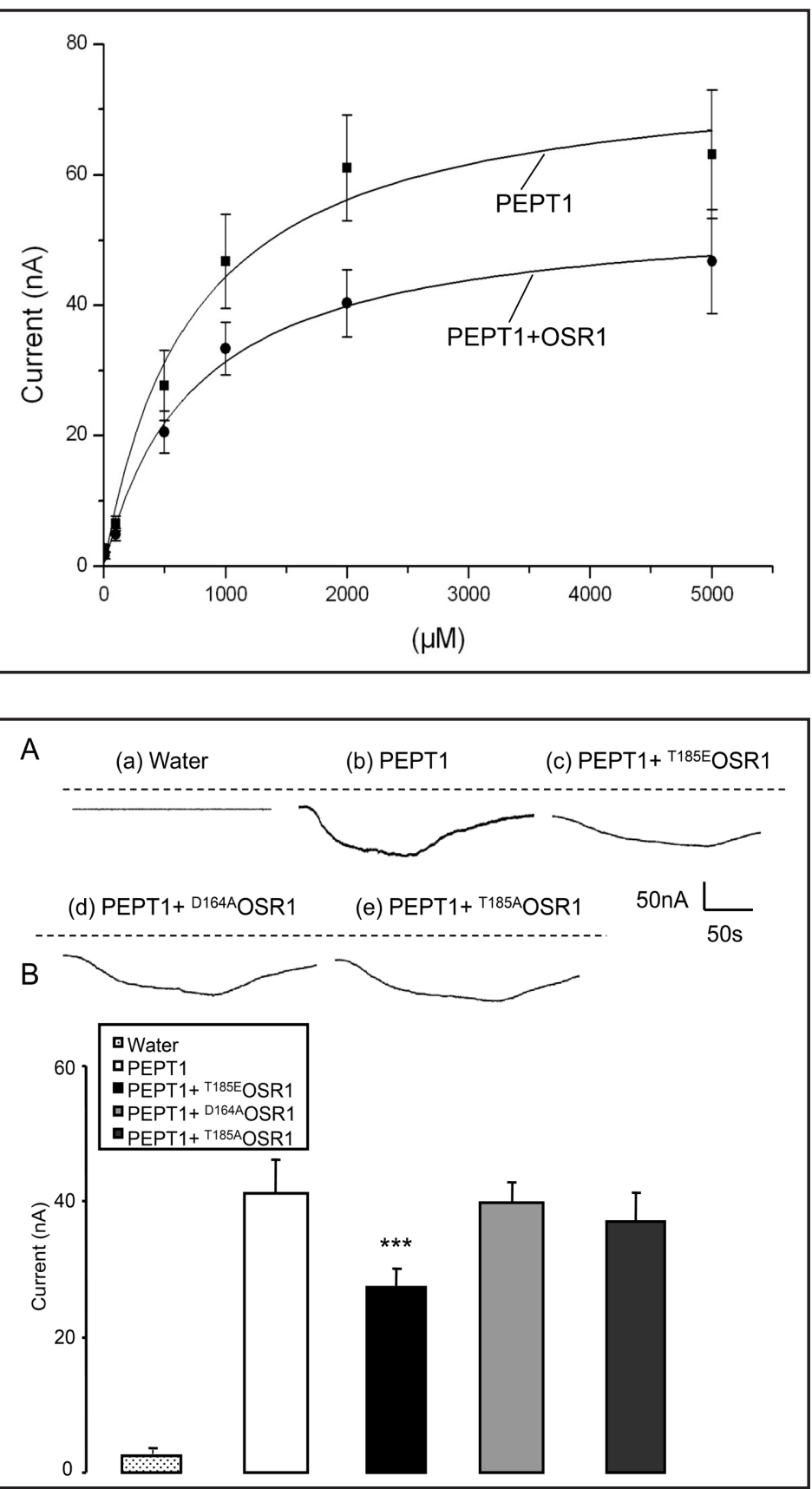

significantly different between Xenopus oocytes expressing PEPT1 alone $(795 \pm 95 \mu \mathrm{M}, \mathrm{n}=$ 10-12) and in Xenopus oocytes expressing PEPT1 together with OSR1 (684 $\pm 63 \mu \mathrm{M}, \mathrm{n}=10$ 12).

Further experiments explored whether the effect of OSR1 was dependent on kinase activity. As illustrated in Fig. 3, similar to wild type OSR1, the constitutively active ${ }^{\text {T185E }}$ OSR1 decreased $\mathrm{I}_{\text {gly-gly }}$. In contrast, neither the catalytically inactive ${ }^{\mathrm{D} 164 \mathrm{~A}}$ OSR1 nor the WNK1 insensitive inactive ${ }^{\mathrm{T} 185 \mathrm{~A}} \mathrm{OSR} 1$ significantly affected $\mathrm{I}_{\text {gly-gly }}$ in PEPT1 expressing Xenopus oocytes.

A further series of experiments tested whether OSR1 similarly influences the peptide transporter isofom PEPT2. Similar to what has been observed in Xenopus oocytes expressing PEPT1, in Xenopus oocytes injected with cRNA encoding PEPT2 addition of glycine-glycine 


\section{Kidney \\ Blood Pressure Research}

Kidney Blood Press Res 2014;39:591-599

DOI: 10.1159/000368469

Publisned onIIne: vecember 15, 2014

(c) 2014 S. Karger AG, Basel

www.karger.com/kbr

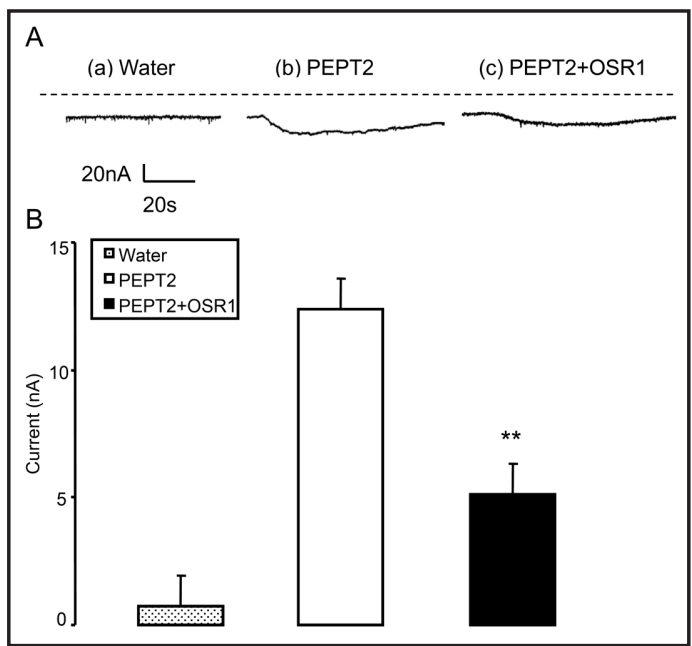

Fig. 4. Coexpression of OSR1 decreases electrogenic peptide transport in PEPT2-expressing Xenopus oocytes. A: Representative original tracings showing glycine-glycine (2 $\mathrm{mM})$ - induced current $\left(\mathrm{I}_{\text {gly-gly }}\right)$ in Xenopus oocytes injected with water (a) or expressing PEPT2 without (b) or with additional coexpression of wild type OSR1 (c). B: Arithmetic means \pm SEM $(n=16-18)$ of glycine-glycine $(2 \mathrm{mM})$ - induced current $\left(\mathrm{I}_{\text {gly-gly }}\right)$ in Xenopus oocytes injected with water (dotted bar), or expressing PEPT2 without (white bar) or with (black bar) wild type OSR1. ${ }^{* *}(\mathrm{p}<0.01)$ indicates statistically significant difference from the absence of OSR1.

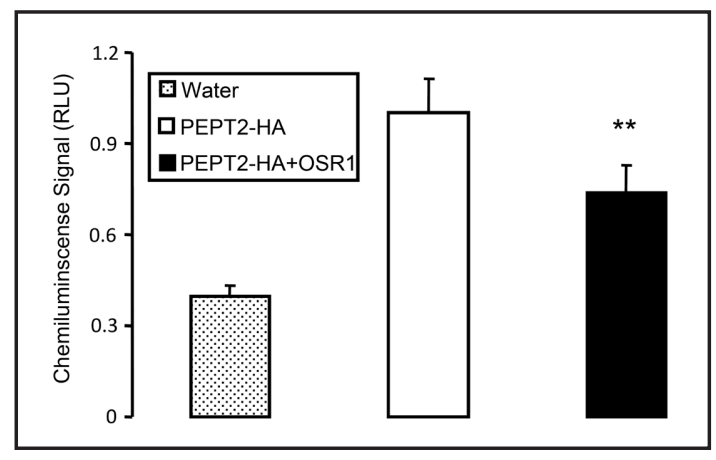

Fig. 5. OSR1 coexpression decreases PEPT2 protein abundance in the Xenopus laevis oocyte cell membrane. Arithmetic means \pm SEM $(n=72-73)$ of PEPT2 protein abundance determined by chemiluminescence in Xenopus laevis oocytes injected with water (dotted bar) or expressing PEPT2-HA alone (white bar), or expressing PEPT2-HA together with wildtype OSR1 (black bar). ${ }^{* *}(\mathrm{p}<0.01)$ indicates statistically significant difference from Xenopus laevis oocytes expressing PEPT2 alone (Kruskal-Wallis test).

to the bath was followed by the appearance

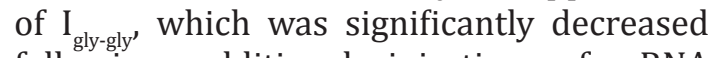
following additional injection of cRNA encoding wild type OSR1 (Fig. 4). The down-regulation of $I_{\text {gly-gly }}$ in PEPT1 or PEPT2expressing Xenopus laevis oocytes following coexpression of OSR1 could have resulted from a decline of protein abundance in the cell membrane. Thus, chemiluminescence was employed to quantify the carrier protein abundance in the cell membrane. As illustrated in Fig. 5, coexpression of wild-type OSR1 resulted in a significant decrease of the PEPT2 protein abundance in the cell membrane of PEPT2 expressing Xenopus laevis oocytes.

\section{Discussion}

The present study discloses a novel function of the oxidative-stress-responsive kinase 1 (OSR1), i.e. the down-regulation of the peptide transporter isoforms PEPT1 and PEPT2. Electrogenic dipeptide transport in PEPT1 expressing Xenopus oocytes was significantly decreased by coexpression of OSR1, of constitutively active ${ }^{\mathrm{T} 185 \mathrm{E}} \mathrm{OSR} 1$, but not of kinase dead ${ }^{\mathrm{D} 164 \mathrm{~A}}$ OSR1 or WNK1 insensitive inactive ${ }^{\mathrm{T} 185 \mathrm{~A}} \mathrm{OSR} 1$. The inefficacy of the mutants indicates that the effect of OSR1 may require kinase activity. According to chemiluminescence the effect is at least in part due to a decrease of (PEPT2) carrier protein abundance in the cell membrane. Along those lines, OSR1 decreases the maximal transport rate without appreciably influencing the affinity of the (PEPT1) carrier.

The present observations reveal the ability of OSR1 to modify PEPT1 and PEPT2 peptide transporter activities. To which extent those effects are relevant for the regulation of peptide transport in vivo, remains, however, to be shown. It must be kept in mind that the expression level of the kinase or the transporters as well as signaling molecules regulating OSR1 and/ or the peptide transporters may be different in the oocyte expression system and given cells in mammalian organisms. 


\section{Kidney Blood Pressure Research}

The peptide transporters accomplish cellular uptake of peptides into renal [48] and intestinal [31, 49] epithelial cells. Moreover, the peptide transporters are expressed in pancreatic cancer cells [50] and prostate cancer cells [51]. Substrates of peptide transporters include several drugs, such as beta-lactam antibiotics, angiotensin-converting enzyme inhibitors, antiviral drugs, and anti-cancer agents [31, 49, 52-55]. The peptide transporters thus participate in cellular drug uptake $[30,38,56,57]$ and the carriers may be potential targets for tumor therapy [51].

Regulators of OSR1 include dietary salt [58], vasopressin $[59,60]$ and insulin $[61,62]$. Whether or not regulation of OSR1 by dietary salt, vasopressin or insulin contributes to the regulation of peptide transporters remains to be shown.

\section{Conclusion}

OSR1 has the potency to downregulate the peptide transporters PEPT1 and PEPT2. Further experiments are needed to define the in vivo significance of OSR1 sensitive peptide transport.

\section{Disclosure Statement}

The authors of this manuscript state that they do not have any conflict of interests and nothing to disclose.

\section{Acknowledgements}

The authors acknowledge the meticulous preparation of the manuscript by Lejla Subasic and technical support by Elfriede Faber. This study was supported by the Deutsche Forschungsgemeinschaft, GRK 1302, SFB 773 B4/A1, La 315/13-3 and the Open Access Publishing Fund of Tuebingen University.

\section{References}

1 Dimke H: Exploring the intricate regulatory network controlling the thiazide-sensitive NaCl cotransporter (NCC). Pflugers Arch 2011;462:767-777.

2 Mercier-Zuber A, O'Shaughnessy KM: Role of SPAK and OSR1 signalling in the regulation of $\mathrm{NaCl}$ cotransporters. Curr Opin Nephrol Hypertens 2011;20:534-540.

3 Richardson C, Alessi DR: The regulation of salt transport and blood pressure by the WNK-SPAK/OSR1 signalling pathway. J Cell Sci 2008;121:3293-3304.

4 Sengupta S, Lorente-Rodriguez A, Earnest S, Stippec S, Guo X, Trudgian DC, Mirzaei H, Cobb MH: Regulation of OSR1 and the sodium, potassium, two chloride cotransporter by convergent signals. Proc Natl Acad Sci USA 2013;110:18826-18831.

5 Vitari AC, Deak M, Morrice NA, Alessi DR: The WNK1 and WNK4 protein kinases that are mutated in Gordon's hypertension syndrome phosphorylate and activate SPAK and OSR1 protein kinases. Biochem J 2005;391:17-24.

6 Vitari AC, Thastrup J, Rafiqi FH, Deak M, Morrice NA, Karlsson HK, Alessi DR: Functional interactions of the SPAK/OSR1 kinases with their upstream activator WNK1 and downstream substrate NKCC1. Biochem J 2006;397:223-231.

7 Kahle KT, Rinehart J, Lifton RP: Phosphoregulation of the Na-K-2Cl and K-Cl cotransporters by the WNK kinases. Biochim Biophys Acta 2010;1802:1150-1158. 


\section{Kidney \\ Blood Pressure Research}

-8 Delpire E, Gagnon KB: SPAK and OSR1, key kinases involved in the regulation of chloride transport. Acta Physiol (Oxf) 2006;187:103-113.

-9 Delpire E, Gagnon KB: SPAK and OSR1: STE20 kinases involved in the regulation of ion homoeostasis and volume control in mammalian cells. Biochem J 2008;409:321-331.

$\checkmark 10$ Gimenez I: Molecular mechanisms and regulation of furosemide-sensitive Na-K-Cl cotransporters. Curr Opin Nephrol Hypertens 2006;15:517-523.

11 Richardson C, Sakamoto K, de los Heros P, Deak M, Campbell DG, Prescott AR, Alessi DR: Regulation of the NKCC2 ion cotransporter by SPAK-OSR1-dependent and -independent pathways. J Cell Sci 2011;124:789800.

12 Gagnon KB, Delpire E: On the substrate recognition and negative regulation of SPAK, a kinase modulating $\mathrm{Na}+-\mathrm{K}+-2 \mathrm{Cl}$ - cotransport activity. Am J Physiol Cell Physiol 2010;299:C614-C620.

13 Glover M, O'Shaughnessy KM: SPAK and WNK kinases: a new target for blood pressure treatment? Curr Opin Nephrol Hypertens 2011;20:16-22.

14 Huang CL, Yang SS, Lin SH: Mechanism of regulation of renal ion transport by WNK kinases. Curr Opin Nephrol Hypertens 2008;17:519-525.

-15 Lin SH, Yu IS, Jiang ST, Lin SW, Chu P, Chen A, Sytwu HK, Sohara E, Uchida S, Sasaki S, Yang SS: Impaired phosphorylation of $\mathrm{Na}(+)-\mathrm{K}(+)-2 \mathrm{Cl}(-)$ cotransporter by oxidative stress-responsive kinase-1 deficiency manifests hypotension and Bartter-like syndrome. Proc Natl Acad Sci USA 2011;108:17538-17543.

16 Villa F, Deak M, Alessi DR, van Aalten DM: Structure of the OSR1 kinase, a hypertension drug target. Proteins 2008;73:1082-1087.

17 Grimm PR, Taneja TK, Liu J, Coleman R, Chen YY, Delpire E, Wade JB, Welling PA: SPAK isoforms and OSR1 regulate sodium-chloride co-transporters in a nephron-specific manner. J Biol Chem 2012;287:3767337690.

18 Hoffmann EK, Schettino T, Marshall WS: The role of volume-sensitive ion transport systems in regulation of epithelial transport. Comp Biochem Physiol A Mol Integr Physiol 2007;148:29-43.

19 Flatman PW: Cotransporters, WNKs and hypertension: an update. Curr Opin Nephrol Hypertens 2008;17:186-192.

20 Furgeson SB, Linas S: Mechanisms of type I and type II pseudohypoaldosteronism. J Am Soc Nephrol 2010;21:1842-1845.

21 Uchida S: Pathophysiological roles of WNK kinases in the kidney. Pflugers Arch 2010;460:695-702.

22 Wilson FH, Disse-Nicodeme S, Choate KA, Ishikawa K, Nelson-Williams C, Desitter I, Gunel M, Milford DV, Lipkin GW, Achard JM, Feely MP, Dussol B, Berland Y, Unwin RJ, Mayan H, Simon DB, Farfel Z, Jeunemaitre X, Lifton RP: Human hypertension caused by mutations in WNK kinases. Science 2001;293:1107-1112.

23 Glover M, Zuber AM, O'Shaughnessy KM: Hypertension, dietary salt intake, and the role of the thiazidesensitive sodium chloride transporter NCCT. Cardiovasc Ther 2011;29:68-76.

-24 O'Reilly M, Marshall E, Speirs HJ, Brown RW: WNK1, a gene within a novel blood pressure control pathway, tissue-specifically generates radically different isoforms with and without a kinase domain. J Am Soc Nephrol 2003;14:2447-2456.

-25 Achard JM, Disse-Nicodeme S, Fiquet-Kempf B, Jeunemaitre X: Phenotypic and genetic heterogeneity of familial hyperkalaemic hypertension (Gordon syndrome). Clin Exp Pharmacol Physiol 2001;28:1048-1052.

-26 Capasso G, Cantone A, Evangelista C, Zacchia M, Trepiccione F, Acone D, Rizzo M: Channels, carriers, and pumps in the pathogenesis of sodium-sensitive hypertension. Semin Nephrol 2005;25:419-424.

27 Pathare G, Foller M, Daryadel A, Mutig K, Bogatikov E, Fajol A, Almilaji A, Michael D, Stange G, Voelkl J, Wagner CA, Bachmann S, Lang F: OSR1-sensitive renal tubular phosphate reabsorption. Kidney Blood Press Res 2012;36:149-161.

28 Pathare G, Foller M, Michael D, Walker B, Hierlmeier M, Mannheim JG, Pichler BJ, Lang F: Enhanced FGF23 serum concentrations and phosphaturia in gene targeted mice expressing WNK-resistant SPAK. Kidney Blood Press Res 2012;36:355-364.

29 Pasham V, Rotte A, Yang W, Zelenak C, Bhandaru M, Foller M, Lang F: OSR1-sensitive regulation of Na+/H+ exchanger activity in dendritic cells. Am J Physiol Cell Physiol 2012;303:C416-426.

-30 Inoue M, Terada T, Okuda M, Inui K: Regulation of human peptide transporter 1 (PEPT1) in gastric cancer cells by anticancer drugs. Cancer Lett 2005;230:72-80.

31 Rubio-Aliaga I, Daniel H: Peptide transporters and their roles in physiological processes and drug disposition. Xenobiotica 2008;38:1022-1042. 


\section{Kidney \\ Blood Pressure Research}

Kidney Blood Press Res 2014;39:591-599

\begin{tabular}{l|l}
\hline DOI: $10.1159 / 000368469$ & (C) 2014 S. Karger AG, Basel
\end{tabular}

Published online: December 15, 2014

www.karger.com/kbr

-32 Ingersoll SA, Ayyadurai S, Charania MA, Laroui H, Yan Y, Merlin D: The role and pathophysiological relevance of membrane transporter PepT1 in intestinal inflammation and inflammatory bowel disease. Am J Physiol Gastrointest Liver Physiol 2012;302:G484-G492.

-33 Rexhepaj R, Dermaku-Sopjani M, Gehring EM, Sopjani M, Kempe DS, Foller M, Lang F: Stimulation of electrogenic glucose transport by glycogen synthase kinase 3. Cell Physiol Biochem 2010;26:641-646.

-34 Yarandi SS, Hebbar G, Sauer CG, Cole CR, Ziegler TR: Diverse roles of leptin in the gastrointestinal tract: modulation of motility, absorption, growth, and inflammation. Nutrition 2011;27:269-275.

-35 Alteheld B, Evans ME, Gu LH, Ganapathy V, Leibach FH, Jones DP, Ziegler TR: Alanylglutamine dipeptide and growth hormone maintain PepT1-mediated transport in oxidatively stressed Caco-2 cells. J Nutr 2005;135:19-26.

-36 Rexhepaj R, Rotte A, Pasham V, Gu S, Kempe DS, Lang F: PI3 kinase and PDK1 in the regulation of the electrogenic intestinal dipeptide transport. Cell Physiol Biochem 2010;25:715-722.

37 Boehmer C, Palmada M, Klaus F, Jeyaraj S, Lindner R, Laufer J, Daniel H, Lang F: The peptide transporter PEPT2 is targeted by the protein kinase SGK1 and the scaffold protein NHERF2. Cell Physiol Biochem 2008;22:705-714.

38 Pieri M, Christian HC, Wilkins RJ, Boyd CA, Meredith D: The apical (hPepT1) and basolateral peptide transport systems of Caco-2 cells are regulated by AMP-activated protein kinase. Am J Physiol Gastrointest Liver Physiol 2010;299:G136-G143.

-39 Hosseinzadeh Z, Dong L, Bhavsar SK, Warsi J, Almilaji A, Lang F: Upregulation of peptide transporters PEPT1 and PEPT2 by Janus kinase JAK2. Cell Physiol Biochem 2013;31:673-682.

40 Hosseinzadeh Z, Bhavsar SK, Lang F: Down-regulation of the myoinositol transporter SMIT by JAK2. Cell Physiol Biochem 2012;30:1473-1480.

-41 Hosseinzadeh Z, Bhavsar SK, Lang F: Downregulation of ClC-2 by JAK2. Cell Physiol Biochem 2012;29:737742.

-42 Alesutan I, Sopjani M, Dermaku-Sopjani M, Munoz C, Voelkl J, Lang F: Upregulation of Na-coupled glucose transporter SGLT1 by Tau tubulin kinase 2. Cell Physiol Biochem 2012;30:458-465.

43 Henrion U, Zumhagen S, Steinke K, Strutz-Seebohm N, Stallmeyer B, Lang F, Schulze-Bahr E, Seebohm G: Overlapping cardiac phenotype associated with a familial mutation in the voltage sensor of the KCNQ1 channel. Cell Physiol Biochem 2012;29:809-818.

44 Mia S, Munoz C, Pakladok T, Siraskar G, Voelkl J, Alesutan I, Lang F: Downregulation of Kv1.5 K channels by the AMP-activated protein kinase. Cell Physiol Biochem 2012;30:1039-1050.

45 Hosseinzadeh Z, Bhavsar SK, Sopjani M, Alesutan I, Saxena A, Dermaku-Sopjani M, Lang F: Regulation of the glutamate transporters by JAK2. Cell Physiol Biochem 2011;28:693-702.

46 Pakladok T, Almilaji A, Munoz C, Alesutan I, Lang F: PIKfyve sensitivity of hERG channels. Cell Physiol Biochem 2013;31:785-794.

-47 Bogatikov E, Munoz C, Pakladok T, Alesutan I, Shojaiefard M, Seebohm G, Foller M, Palmada M, Bohmer C, Broer S, Lang F: Up-regulation of amino acid transporter SLC6A19 activity and surface protein abundance by PKB/Akt and PIKfyve. Cell Physiol Biochem 2012;30:1538-1546.

-48 Terada T, Inui K: Recent advances in structural biology of peptide transporters. Curr Top Membr 2012;70:257-274.

49 Meredith D: Review. The mammalian proton-coupled peptide cotransporter PepT1: sitting on the transporter-channel fence? Philos Trans R Soc Lond B Biol Sci 2009;364:203-207.

50 Gonzalez DE, Covitz KM, Sadee W, Mrsny RJ: An oligopeptide transporter is expressed at high levels in the pancreatic carcinoma cell lines AsPc-1 and Capan-2. Cancer Res 1998;58:519-525.

51 Tai W, Chen Z, Cheng K: Expression Profile and Functional Activity of Peptide Transporters in Prostate Cancer Cells. Mol Pharm 2013;10:477-487.

52 Newstead S: Towards a structural understanding of drug and peptide transport within the protondependent oligopeptide transporter (POT) family. Biochem Soc Trans 2011;39:1353-1358.

53 Brandsch M: Transport of drugs by proton-coupled peptide transporters: pearls and pitfalls. Expert Opin Drug Metab Toxicol 2009;5:887-905.

54 Kamal MA, Keep RF, Smith DE: Role and relevance of PEPT2 in drug disposition, dynamics, and toxicity. Drug Metab Pharmacokinet 2008;23:236-242. 


\section{Kidney \\ Blood Pressure Research}

55 Nakamura T, Yamamori M, Sakaeda T: Pharmacogenetics of intestinal absorption. Curr Drug Deliv 2008;5:153-169.

56 Mitsuoka K, Kato Y, Miyoshi S, Murakami Y, Hiraiwa M, Kubo Y, Nishimura S, Tsuji A: Inhibition of oligopeptide transporter suppress growth of human pancreatic cancer cells. Eur J Pharm Sci 2010;40:202208.

57 Tsume Y, Hilfinger JM, Amidon GL: Enhanced cancer cell growth inhibition by dipeptide prodrugs of floxuridine: increased transporter affinity and metabolic stability. Mol Pharm 2008;5:717-727.

58 Chiga M, Rai T, Yang SS, Ohta A, Takizawa T, Sasaki S, Uchida S: Dietary salt regulates the phosphorylation of OSR1/SPAK kinases and the sodium chloride cotransporter through aldosterone. Kidney Int 2008;74:1403-1409.

59 Pedersen NB, Hofmeister MV, Rosenbaek LL, Nielsen J, Fenton RA: Vasopressin induces phosphorylation of the thiazide-sensitive sodium chloride cotransporter in the distal convoluted tubule. Kidney Int 2010;78:160-169.

60 Saritas T, Borschewski A, McCormick JA, Paliege A, Dathe C, Uchida S, Terker A, Himmerkus N, Bleich M, Demaretz S, Laghmani K, Delpire E, Ellison DH, Bachmann S, Mutig K: SPAK differentially mediates vasopressin effects on sodium cotransporters. J Am Soc Nephrol 2013;24:407-418.

61 Nishida H, Sohara E, Nomura N, Chiga M, Alessi DR, Rai T, Sasaki S, Uchida S: Phosphatidylinositol 3-kinase/ Akt signaling pathway activates the WNK-OSR1/SPAK-NCC phosphorylation cascade in hyperinsulinemic db/db mice. Hypertension 2012;60:981-990.

62 Sohara E, Rai T, Yang SS, Ohta A, Naito S, Chiga M, Nomura N, Lin SH, Vandewalle A, Ohta E, Sasaki S, Uchida $\mathrm{S}$ : Acute insulin stimulation induces phosphorylation of the $\mathrm{Na}-\mathrm{Cl}$ cotransporter in cultured distal mpkDCT cells and mouse kidney. PLoS One 2011;6:e24277. 